\title{
Model of Relationship Marketing and E-Commerce in Improving Marketing Performance of Batik SMEs
}

\author{
Naili Farida ${ }^{1}{ }$ Agus Naryoso $^{1}$, Ahyar Yuniawan ${ }^{2}$ \\ ${ }^{1}$ Faculty of Social and Political Science, University of Diponegoro, Semarang, Indonesia \\ ${ }^{2}$ Faculty of Economics and Business, University of Diponegoro, Semarang, Indonesia
}

\section{Info Article}

History Article:

Received Januari 2017

Approved Februari 2017

Published Maret 2017

\section{Keywords:}

Relationship Marketing, E-

Commerce, SME Marketing

Performance.

\begin{abstract}
Various models of relationship marketing were developed with the aim to create sustainable performance. Old model of marketing is a conventional marketing that only rely on face to face marketing. However, in line with the advances in market information technology, customers should be pampered and served well. E-commerce and E-business is the application of business operations conducted through the Internet so that it can expand product marketing both in national and international markets. The purpose of this study is to develop and test models of relationship marketing, that is, the relationship among determinants of marketing performance increase. Sample in this study is 41 Batik SME owners in Semarang City. The analysis used in this study is the SEM-PLS. Data processing in this study uses the Smart PLS. The results of this study indicate that: (1) social capital has no influence on market capabilities; (2) relationship quality has influence on market capabilities; (3) entrepreneurial orientation has influence on social capital; (4) market capabilities has influence on marketing performance; (5) e-commerce has influence on marketing performance, meaning that a better e-commerce or online marketing will be able to improve the marketing performance of SMEs.
\end{abstract}

\section{Model Pemasaran Hubungan dan E-Commerce dalam Meningkatkan Kinerja Pemasaran UKM Batik}

\begin{abstract}
Abstrak
Berbagai model pemasaran hubungan dikembangkan dengan tujuan untuk menciptakan kinerja yang berkelanjutan. Model pemasaran lama adalah pemasaran konvensional yang hanya mengandalkan tatap muka pemasaran. Namun, seiring dengan kemajuan teknologi informasi pasar, nasabah harus dimanjakan dan terlayani dengan baik. Tujuan dari penelitian ini adalah untuk mengembangkan dan menguji model hubungan pemasaran, yaitu hubungan antara faktor penentu peningkatan kinerja pemasaran. Sampel dalam penelitian ini adalah 41 pemilik UKM Batik di Kota Semarang. Analisis yang digunakan dalam penelitian ini adalah SEM-PLS. Pengolahan data dalam penelitian ini menggunakan Smart PLS. Hasil penelitian ini menunjukkan bahwa: (1) modal sosial tidak berpengaruh terhadap kemampuan pasar; (2) kualitas hubungan berpengaruh terhadap kemampuan pasar; (3) Orientasi kewirausahaan berpengaruh terhadap modal sosial; (4) kemampuan pasar berpengaruh terhadap kinerja pemasaran; (5) e-commerce berpengaruh terhadap kinerja pemasaran.
\end{abstract}

JEL Classification: M3, M31

$\begin{array}{lr}{ }^{凶} \text { Correspondence Address } & \text { ISSN } \\ \text { Prof. Soedharto, SH Tembalang, Semarang, Jawa Tengah 50275 } & 2086-0668 \text { (print) } \\ \text { Email: faridanaili@ymail.com } & 2337-5434 \text { (online) }\end{array}$


Naili Farida, et al. / Model of Relationship Marketing and E-Commerce in...

\section{INTRODUCTION}

One of the products of creative industry is Batk which is an Indonesian art and cultural product. This is reflected in the unique design and style describing cultural heritage ofeach region. Semarang has a typical culture that is "Batik Semarang”. Today, Batik products are more and more liked by Indonesian consumers as a cultural work that is recognized worldwide by UNESCO. Batik is different from other cultural products since its motif and design is the characteristic and pride of the Indonesian.

Batik products are mostly from artisans or inherited from parents who have a batik business so that the business is passed on from one generation to the next, traditionally. The current Batik small enterprisesor small-medium enterprises (SMEs) are still traditional because they have not been managed professionally. Besides, they still use transactional marketing so there needs to be a change into relationship marketing.

Batik experiences a significant growth. Ministry of Industry explained that Batik has a very high economic value that can be seen from the value of batik exports (kemenperin.go.id). Batik export value increased by $10 \%$ in 2015 amounted to Rp. 2.1 trillion. The value of exports is what makes batik able to contribute significantly to the economy of Indonesia. The main focus in this study is relationship marketing, e-commerce and marketing performance of SMEs.

Old model of marketing is a conventional marketing that only rely on face to face marketing. However, in line with the advances in market information technology, customers should be pampered and served well so that they do not turn to another company, even become loyal to the company (Syafruddin, 2003) .Other marketing expert's claim that relationship marketing is the same as Customer Relationship marketing, there is also a term Customer Relationship Management (CRM). Customer Relationship marketing is the marketing practices in business that is focused/oriented on customer (Buttle, 2004).
In a global, all-digital era, small and medium enterprises (SMEs) have to adapt to the change through information technology. In business, there is E-commerce and E-business that is the application of business operations conducted through the Internet so that it can expand product marketing both in national and international markets. Business operation that can be run by companies or SMEs include: eMarketing, e-Promotion, (marketing and interactive promotions). e-schedule, e-tailing (online retail). e-product, e-commerce (online business transactions). e payment and e-Service (Tjiptono et al., 2012).

Performance is an important part of a business, in this case is Batik SMEs. There are some important factors that can affect marketing performance. First, innovation. Innovation in services has led to the greatest level of growth and dynamism over the last few years in economic activity (McDermott et al., 2012). Basically the success of SMEs in innovation will be able to improve the performance of SMEs (Ardyan, 2016). McDermott et al., 2012) view innovation into two types of exploratory and exploitation of innovation both of which can improve performance, particularly in SMEs.

Other studies have also found that innovation can influence performance significantly (Otero-Neira et al., 2009; Zheng et al., 2009; Airs et al., 2013). Second, the use of e-commerce. One of the characteristics of e-commerce is a rapid scale of expansion (Yang et al., 2016) so that the use of e-commerce make market reach of SMEs Batik become more widespread. The use of search engine marketing as part of ecommerce can improve the company's performance significantly. Third, market capability. Market capability can be in the form of business environment understanding, changes in design creation, product uniqueness functionality and competition capabilities (Narver et al., 1990).

Market capability will enable SMEs to create maximum performance (Farida, 2016). Fourth, social capital. Social capital is important in the Batik SMEs. One of the significance of so- 
cial capital is its impact on the performance of Batik SMEs (Ismail, 2015).

The purpose of this study is to develop and test models of relationship marketing, that is the relationship among determinants of marketing performance increase. The proposed research questions are as follows:

Q1. Does social capital affect market capability?

Q2. Does relationship quality affect market capability?

Q3. Does entrepreneurship orientation affect social capital?

Q4. Does market capability affect marketing performance?

Q5. Does e-commerce affect marketing performance?

\section{Hypothesis Development}

\section{Social Capital and Market Capability}

A success in managing a business, one of which, is influenced by socal capital. Cohen et al. 2001) defines social capital as the supply of connections among individuals as well as social networks, and reciprocity norms as well as mutual trusts arising from the connections. Further, Ferdinand (2005) states that the organizational networks built upon norms along with a system of values and a common understanding can strengthen cooperation and long-term organizational cohesion. Next, social capital will work together with both internal and external environment, creation, innovation and product capability.

H1: Social Capital affects Market Capability.

\section{Relationship Quality and Market Capability}

The first year of research had been carried out and identified the implementation of marketing relationship between companies or SMEs with distributors. One of the variabels used was relationship quality. Relationship qualityaccording to De Wulf et al. 2000) has three indicators: 1) Communication, 2) conflict, 3 ) commitment to improve the relationship between the company and customers. Relationships quality is related to market ca- pability that has the resources and conditions underlying the performance of companies or SMEs. According to Barney (1991). the concept of Resource Based View is the basis of market capabilities, thus, it is built the following hypothesis:

H2: Relationship Quality affects MarketCapabilitiies.

\section{Social Capital and Entrepreneurship Orientation}

The success of a company is the success of a business, and one of the important factors that determines the success of a business is social capital. Social capital has five indicators: 1 ) Network relationship, 2) social networking, 3) social cohesion, 4) trust and mutual trust and 5) social norms. Social capital is also affected by entrepreneurial orientation which has the following indicators: 1) business experience, 2) pro active, 3) the ability to take risks, 4) Flexibility, and 5) Anticipative. Social capital owned by SMEspractitioners supported by a strong entrepreneurial orientation will improve marketing performance (Nugroho, 2015). Thus constructed the following hypothesis:

H3: Entrepreneurship Orientation affects Social Capital.

\section{Market Capability and Marketing Performance}

According to Barney (1991) concept of Value Based Resources (RBV) is based on company resource-based approach and the conditions underlying the performance of a company. Acompany is an organization covering a set of resources and unique capabilities as the basis for determining the company's strategy and the key sources of return or income of the company. Further, dynamic capability is inherent in the process and routines of organizational activities to enhance creativity to adapt to the growing demands of market conditions so that it can increase company's ability to win the competition (Pavlou et al., 2011). Dynamic capability development requires the active role of the two factors, that is, knowledge resource and learning mechanisms. 
Naili Farida, et al. / Model of Relationship Marketing and E-Commerce in...

Then, Chien et al. (2012) explains that knowledge resource is a critical-strategic resource and contributes to achieve comparative advantage and lead to the development of dynamic capabilities. Meanwhile, learning mechanism will improve dynamic capacity. Then, the following hypothesis is built:

H4: Market Capability affects Marketing Performance.

\section{E- Commerce and Marketing Performance}

In the present globalization era, marketing is not only limited to face-to-face, but marketing with the online system via the Internet, or the socalled E-Commerce business. E-Commerce will be able to improve product marketing and expand market both nationally and internationally. E-Commerce has indicators: Online Purchase Prospective, Digital Communication Perspective, Service Perspective and Bussiness Process Perspective. E-Commerce practice will be able to expand SMEs marketing range, increase demand, maintain and develop relationships with distributors, customers and suppliers quickly and on time (Salwani et al., 2009).. Thus, the following hypothesis is built:

H5: E-commerce affects Marketing Performance

\section{METHOD}

The population in this study is all owners of SMEs who have established relationships with artisans from various Batik SMEs in Semarang. This study uses a purposive sampling technique with the criteria: 1) SMEs stand at least 2 years, 2) Owners of SMEs domicile in the city of Semarang, 3) SMEs owners are willing to be interviewed

Before performing the deployment, researchers asked beforehand about the three criteria of sample to the respondent. If the three conditions are met, the researchers asked respondents to fill in the questionnaire. Questionnaires were distributed to 41 respondents (owners of SMEs Batik). All questionnaires were returned and the data obtained can be used for further analysis. Table 1 describes the characteristics of respondents.
Table 1. Characteristics of Respondents

\begin{tabular}{|c|c|}
\hline Gender & Frequency $(\%)$ \\
\hline Male & $14.6 \%$ \\
\hline Female & $85.4 \%$ \\
\hline Age Group & Frequency $(\%)$ \\
\hline $36-43$ years old & $36.6 \%$ \\
\hline $44-51$ years old & $52.2 \%$ \\
\hline $52-59$ years old & $11.2 \%$ \\
\hline Education & Frequency $(\%)$ \\
\hline Senior High School & $56.1 \%$ \\
\hline Diploma & $29.3 \%$ \\
\hline Bachelor & $14.6 \%$ \\
\hline Income & Frequency $(\%)$ \\
\hline$<\mathrm{Rp} 1.000 .000$ & $8.8 \%$ \\
\hline Rp 2.000.000-Rp 3.000.000 & $43.9 \%$ \\
\hline Rp 4.000.000-5.000.000 & $17.1 \%$ \\
\hline$>$ Rp5.000.000 & $34.1 \%$ \\
\hline Length of Cooperation & Frequency $(\%)$ \\
\hline$<1$ year & $17.1 \%$ \\
\hline $2-3$ years & $43.9 \%$ \\
\hline $4-5$ years & $26.8 \%$ \\
\hline$>5$ Tahun & $12.2 \%$ \\
\hline Length of Working & Frequency $(\%)$ \\
\hline$<1$ year & $7.3 \%$ \\
\hline $2-3$ years & $39.1 \%$ \\
\hline $4-5$ years & $31.7 \%$ \\
\hline$>5$ years & $21.9 \%$ \\
\hline Occupation & Frequency $(\%)$ \\
\hline Entrepreneur & $95.1 \%$ \\
\hline Civil Servant & $2.4 \%$ \\
\hline Private Employees & $0 \%$ \\
\hline Others & $2.4 \%$ \\
\hline
\end{tabular}

Reasons for Using Distribu- Frequency (\%) tors

\begin{tabular}{ll}
\hline Able to share & $9.6 \%$ \\
More Channel & $14.4 \%$ \\
Wider Marketing & $62.4 \%$ \\
More Salable Products & $4.8 \%$ \\
More Popular Products & $4.8 \%$ \\
Others & $2,4 \%$ \\
\hline
\end{tabular}




\begin{tabular}{ll}
\hline Facilities & \\
Design of Ordered Batik & $9.6 \%$ \\
Wider Networking & $43.2 \%$ \\
Widespread Customers & $36 \%$ \\
Others & $7.2 \%$ \\
\hline
\end{tabular}

A total of 41 respondents participated in this research is batik artisans in the city of Se- marang. Respondents represent a range of age, education level, and income. A total of 41 respondents are high school graduates (56.1\%). Diploma as much as $29.1 \%$, and Bachelor as much as $14.6 \%$. Respondents are $85.40 \%$ of women and $14.60 \%$ of men. Age of respondents is divided into three categories namely $36-43$ years old as much as $36.60 \%$, 44-51 years old as much as 52.20 and $52-59$ years old as much as $11.20 \%$.

Table 2. Operational Variable

\begin{tabular}{|c|c|c|c|}
\hline No & Name of Variable & Indicator & Source \\
\hline 1. & $\begin{array}{l}\text { Relationship Quality } \\
\text { (RQ) }\end{array}$ & $\begin{array}{l}\text { There are } 3 \text { indicators : } \\
\text { a) Communication } \\
\text { b) Conflict } \\
\text { c) Commitment }\end{array}$ & $\begin{array}{l}\text { Smith (1998); De wulf- } \\
\text { Odeskeben Seroder (2000) }\end{array}$ \\
\hline 2. & Social Capital (SC) & $\begin{array}{l}\text { There are } 5 \text { indicators : } \\
\text { a) Relationship Networking } \\
\text { b) Social Networking } \\
\text { c) Social Cohesion } \\
\text { d) Trust and Mutual Trust } \\
\text { e) Social Norms }\end{array}$ & $\begin{array}{l}\text { Coleman (1988); Cohen et } \\
\text { al. (2001); Ferdinand (2005) }\end{array}$ \\
\hline 3. & $\begin{array}{l}\text { Market Capabilities } \\
(\mathrm{MC})\end{array}$ & $\begin{array}{l}\text { There are } 4 \text { indicators : } \\
\text { a) Environment Understanding } \\
\text { b) Innovation Creation } \\
\text { c) Uniqueness Function } \\
\text { d) Capabilities }\end{array}$ & $\begin{array}{l}\text { Kohli et al. 1990); Narver et } \\
\text { al. (1990); Barney (1991) }\end{array}$ \\
\hline 4. & $\begin{array}{l}\text { Entrepreneurship } \\
\text { Orientation (EO) }\end{array}$ & $\begin{array}{l}\text { There are } 5 \text { indicators : } \\
\text { a) Business Experience } \\
\text { b) Proactive } \\
\text { c) Ability to take risks } \\
\text { d)Flexible } \\
\text { e) Anticipative }\end{array}$ & $\begin{array}{l}\text { Weerawardana (2003); } \\
\text { Griffith et al. (2006); Haroon } \\
\text { et al. (2011) }\end{array}$ \\
\hline 5. & E-Commerce (E) & $\begin{array}{l}\text { There are } 4 \text { indicators : } \\
\text { a) Online Purchasing perspective } \\
\text { b) Digital Communication Perspective } \\
\text { c) Service Perspective } \\
\text { d) Business Process Perspective. }\end{array}$ & $\begin{array}{l}\text { Fandy Tjiptono and Chandra } \\
\text { (2012) }\end{array}$ \\
\hline 6. & $\begin{array}{l}\text { Marketing Perfor- } \\
\text { mance }(\mathrm{MP})\end{array}$ & $\begin{array}{l}\text { There are } 4 \text { indicators : } \\
\text { a) Sale Growth } \\
\text { b) Number of Customers } \\
\text { c) Product Demand } \\
\text { d) Profit Increase }\end{array}$ & $\begin{array}{l}\text { Wiklund (1999); Ferdinand } \\
(2000) \text {; Voss et al. 2000) }\end{array}$ \\
\hline
\end{tabular}


Naili Farida, et al. / Model of Relationship Marketing and E-Commerce in...

Techniques of analysis in this study uses Partial Least Square Structural Equation Modeling (PLS-SEM). To process the data, researchers uses Smart PLS software.

\section{RESULT AND DISCUSSION}

In the research process, after the data is collected, Measurement Model or Outer Model testingis done to measure the reliability and validity of research variable with 3 ways 1 ) convergent validity,) 2) discriminate validity and 3) composite reliability. Outer model result shows profit reliability and validity of each variable in Table. 3, Table 4 and Table 5. According to Ghozali (2008) another test to see Average Varian Extracted (AVE) value of each construct worths 0.50. AVE Table describes that all variables in the estimated model meet the criteria of desciminantvalidity.

Table 3. Value of AVE (Average Variance Extracted) Square Root

\begin{tabular}{lr}
\hline & AVE \\
\hline E-Commerece (E) & 0.6293 \\
Relationship Quality (RQ) & 0.7255 \\
Market Capability (MC) & 0.7896 \\
Social Capital (SC) & 0.8333 \\
Entrepeneurship Orientation (EO) & 0.7014 \\
Marketing (M) & 0.6429 \\
\hline
\end{tabular}

\section{Composite Reliablity}

Composite reliability valueis conducted to test variables, while good variables have a value shown by the composite reliability and Cronbach $>70$. listed in Table 4.

Table 4. Composite Reliability

\begin{tabular}{ll}
\hline & $\begin{array}{l}\text { Composite } \\
\text { Reliability }\end{array}$ \\
\hline E-Commerce & 0.8714 \\
Relationship Quality & 0.9588 \\
Market Capabilities & 0.9375 \\
\hline
\end{tabular}

\begin{tabular}{ll}
\hline Social Capital & 0.9615 \\
Entrepeneurship Orientation & 0.9209 \\
Marketing & 0.8736 \\
\hline
\end{tabular}

\section{Cronbachs alpha}

Cronbahs alpha value in Table 5 shows that all variables have exceeded 0.50 . Table 4 of Composite reliability and Table 5 of Cronbahs alpha show that all variables have good reliability and are qualified.

Table 5. Cronbach’s Alpha

\begin{tabular}{ll}
\hline & $\begin{array}{l}\text { Cronbach's } \\
\text { Alpha }\end{array}$ \\
\hline E-Commerce & 0.8034 \\
Relationship Quality & 0.9506 \\
Market Capabilities & 0.9125 \\
Social Capital & 0.9498 \\
Entrepeneurship Orientation & 0.8913 \\
Marketing & 0.8077 \\
\hline
\end{tabular}

\section{Structural Model Testing (Inner Model)}

The testing result of structural modelis done by looking at the value of R-square which is a test for goodness-fit model, that is to look at the relationship between variables, significance value and R-square of research model. Using PLS analysis, R-square for each research variable influenced by other variables can be seen in Table 6 .

Table 6. R Square

\begin{tabular}{ll}
\hline & R Square \\
\hline E-Commerce & 0 \\
Relationship Quality & 0 \\
Market Capabilities & 0.764 \\
Social Capital & 0.7283 \\
Entrepeneurship Orientation & 0 \\
Marketing & 0.8353 \\
\hline
\end{tabular}

Table 6 can be interpreted as follow: (1) construct variable of Market Capability can be explained by construct variability of Relation- 
ship Quality and Social Capital amounted to $76.40 \%$, while the remaining $23.60 \%$ is explained by other variables outside the research model, 2) construct variable of Social Capital is explained by construct variability of Entrepreneurship Orientation, Market Capability and Marketing Performance amounted to $72.83 \%$, while the remaining $27.17 \%$ is explained by other variables outside the research model. 3 ) construct variable of Marketing Performance can be explained by construct variability of Market Capability and E-commerce (E) amounted to $87.36 \%$ and the remaining $12.64 \%$ is explained by other variables outside the research model.

Table 7 of Coefficient Path shows that the highest value of original sampleis on the relationship between Relationship Quality and Market Capability that is 0.8667 .The lowest value of original sampleis on the relationship bet- ween social capital and Market Capability that is 0.008 . The higest value of Mean sample is on the relationship between Entrepreneurship OrientationandSocial Capital, while the lowest value of mean sample is on the relationship between Social Capital and Market capability that is 0.0604 .

The highest value of Standard Error (Sterr) is on the relationship between social capital and the Market capability that is 0.1595 ; while the lowest value of Sterr ison the relationship betweenMarket capability and Marketing performance that is 0.773 . The highest value of $\mathrm{t}$-statistic is 0.83858 on the relationship between Entrepreneurship orientation andSocial Capital; while the lowest value of $\mathrm{t}$-statistic is 0.0503, on the relationship between Social Capital and Market Capability. $\mathrm{KH}$ : relationship quality (RQ). E: e-commerce (E). KP: market

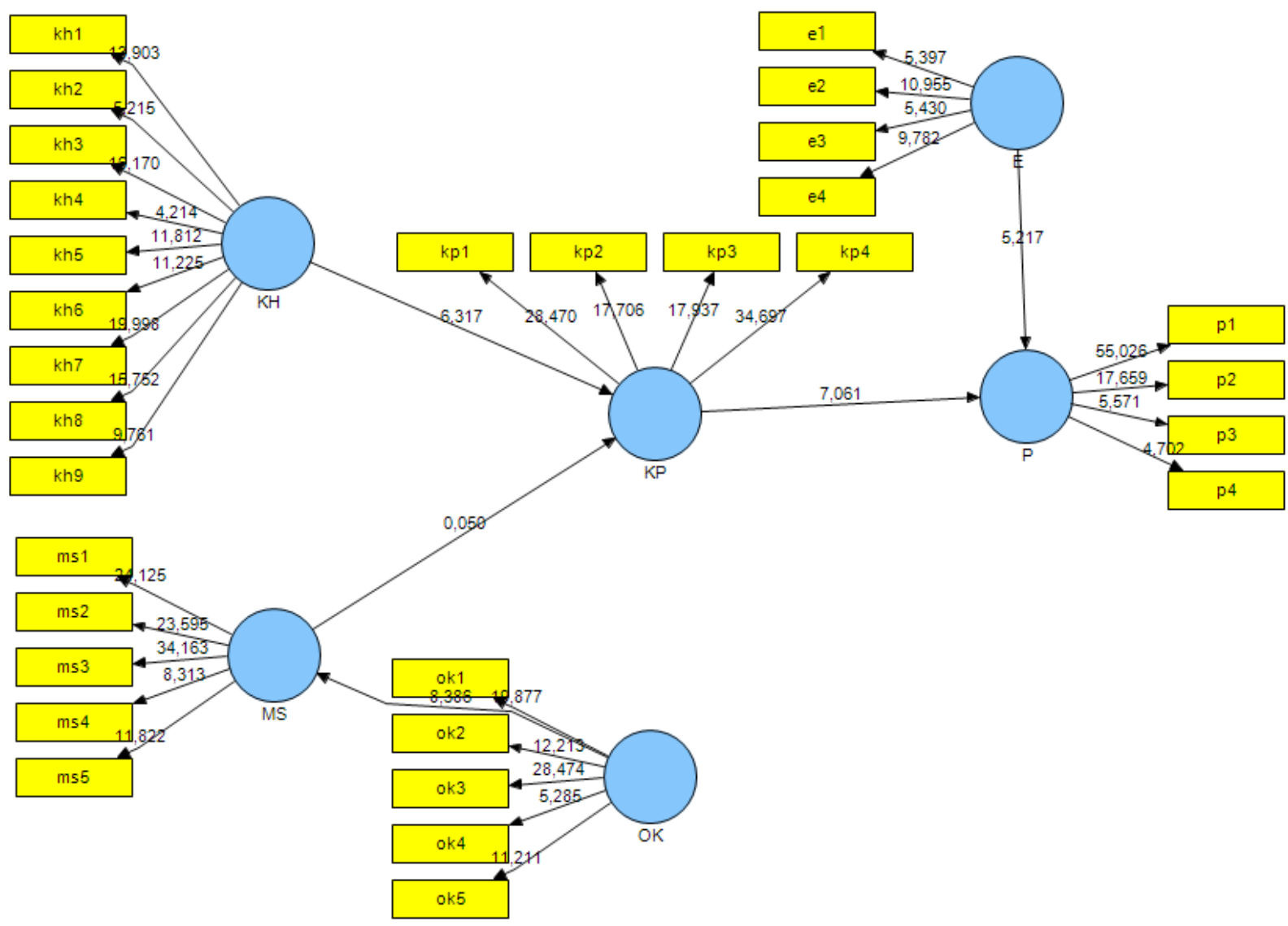

Figure 1. Path Diagram of Model Fit PLS Output 
Naili Farida, et al. / Model of Relationship Marketing and E-Commerce in...

Table 7. Path Coefficients (Mean, STDEV, T-Values)

\begin{tabular}{llllll}
\hline & $\begin{array}{l}\text { Original } \\
\text { Sample }(\mathbf{O})\end{array}$ & $\begin{array}{l}\text { Sample } \\
\text { Mean }(\mathbf{M})\end{array}$ & $\begin{array}{l}\text { Standard Devia- } \\
\text { tion }(\text { STDEV) }\end{array}$ & $\begin{array}{l}\text { Standard Er- } \\
\text { ror }(\text { STERR) }\end{array}$ & $\begin{array}{l}\text { T Statistics } \\
(\mid \mathbf{O} / \text { STERR } \mid)\end{array}$ \\
\hline $\mathrm{E}->\mathrm{P}$ & 0.528 & 0.5225 & 0.1012 & 0.1012 & 5,217 \\
$\mathrm{KH}->\mathrm{KP}$ & 0.8667 & 0.7971 & 0.1372 & 0.1372 & 6,3167 \\
$\mathrm{KP}->\mathrm{P}$ & 0.546 & 0.5296 & 0.0773 & 0.0773 & 7,0607 \\
$\mathrm{MS}->\mathrm{KP}$ & 0.008 & 0.0604 & 0.1595 & 0.1595 & 0.0503 \\
$\mathrm{OK}->\mathrm{MS}$ & 0.8534 & 0.8173 & 0.1018 & 0.1018 & 8,3858 \\
\hline
\end{tabular}

Table 8. Hypothesis Testing Results

\begin{tabular}{llllll}
\hline Hypothesis & Coefficient & $\begin{array}{l}\text { Significance } \\
\text { Rate }\end{array}$ & t-table & t-statistic & Results \\
\hline H1 & 0.008 & $5 \%$ & 1.683 & 0.0503 & H1 rejected \\
H2 & 0.8667 & $5 \%$ & 1.683 & 6.3167 & H2 accepted \\
H3 & 0.8534 & $5 \%$ & 1.683 & 8.3858 & H3 accepted \\
H4 & 0.546 & $5 \%$ & 1.683 & 7.0607 & H4 accepted \\
H5 & 0.528 & $5 \%$ & 1.683 & 5.217 & H5 accepted \\
\hline
\end{tabular}

capability (MC). P: marketing (M). OK: Entrepreneurship Orientation (EO)

In Table 8 , based on bootstrapping hypothesis testing of PLS analysis, it can be concluded that Hypothesis 1 is not supported and Hypothes: 2, 3, 4, and 5 are supported. $\mathrm{H} 1$ is rejected. It means that a good social capital does not affect market capability. This indicates that social capital, that is networking, relationship, cooperation, trust and social cohesion, owned by SMEs are not enough to face market competitors so it is necessary to understand environment by doing creation, innovation of the product so as to have market capability that can compete with other products.

$\mathrm{H} 2$ is accepted. It means that relationship quality has positive and significant influence on market capability. $\mathrm{H} 3$ is accepted. It means that there is a positive and significant influence of Entrepreneurship Orientation on Social Capital with the $\mathrm{t}$-stastics $>\mathrm{t}$ table, $8.3858>1.978$ and the value of mean sample is 0.8173 . There is a positive influence of Entrepreneurship Orientation on Social Capital. Batik artisans or SMEs businessman assume that dealer has perspective that the higher the dealer's skill, the betterthe dealer's entrepreneurship orientation includingexperience, pro-active attitude, the ability to take risks, and being flexible (means that the dealer can market 2 or 3 SMEs as well). While the research findings of Nugroho et al. (2015) showed thatsocial capital, that is structural, relational and cognitive dimensions affect entrepreneurship orientation and organizational performance.

$\mathrm{H} 4$, there is a positive and significant influence ofMarket Capabilityon Marketing Performance t-statistics $>\mathrm{t}$ table $7.0607>1.978$ and the value of sample mean is 0.5296 , so $\mathrm{H} 4$ is accepted. This is in line with the findings of Power (2005) showing that there is positive and significant influence ofMarket Capability on marketing performance in companies in Australia using the sample of as many as 553 members of the EAN organization.

$\mathrm{H} 5$, there is a positive and significant influence of E-Commerce on Marketing Performance, $\mathrm{t}$-statistics $>\mathrm{t}$ table $5.217>1,978$ and the value of mean sample is 0.5225 so $\mathrm{H} 5$ is accepted. 
This study has two implications, that is theoretical and managerial implications. First, theoretical implication. In this research, it is found that social capital has no effect on market capability. Social capital in this study tends to be associated with the network owned by Batik businessman. Networks used are still very simple networking. The simplicity in network causes a significant increase in SMEs market capabilities. Second, managerial implication. SME owners are expected to be able to build a more modern network. There is a concept called Quarteple Helix. It is expected there is a networking connection among SMEs owners, universities, governments, and communities. By having such a network, market capabilities will increase significantly.

\section{CONCLUSIONAND RECOMMENDATION}

Based on the analysis and discussion, it can be concluded that (1) Social Capital does not affect Market Capability. A good social capital is not able to guarantee market capability to compete with similar products. 2) Relationship Quality has positive and significant effect on Market Capability, which means the better the quality of the relationship built between SMEs crafters with suppliers and customers, the better the ability of environment understanding about product information given by suppliers to SMEs, foster innovation creation, uniqueness function and market capabilities of the product.

(3) Entrepreneurship Orientation has a positive and significant impact on Social Capital, meaning that if SMEs have business experience, pro-actively inform the product, have the courage to take risks, being flexible and participative, they will be able to improve relationship networking, social networking, social cohesion, and mutual trust between suppliers and consumers.

(4) Market Capability has a positive and significant effect on Marketing Performance, meaning that the higher SMEs market capabilities, the higher their marketing performance, that is the increased growth in sales volume, an increase in the number of customers, and inc- rease of profits for SMEs. 5) E-commerce has a positive and significant effect on Marketing Performance, meaning thata better e-commerce or online marketing will be able to improve the marketing performance of SMEs

Recommendations of this study (1) SMEs craftsmen or businessman can build a better marketing relationship between SMEs and resellers to realize a long-term cooperation. It can be done by improvingrelationship quality that is communication and commitment with distributors and consumers. 2) SMEs craftsmen or businessman can expand product marketing via e-commerce or online sales.

Limitations of this study is the population in this study is only in urban areas with the number of respondents is limited so it cannot be generalized. For future research study, the population can be expanded to include batik SMEs in Central Java or Indonesia. Research model can be developed by adding variables of market sensing and performance. Analysis techniques for future studies can use Structural Equation Modeling (SEM) and CFI to be more comprehensive.

\section{Acknowledgement}

This research is funded by Hibah Fundamental of Ditlitabmas Ditjen Dikti Kemendikbud Tahun Anggaran 2015 Nomor: 140-32/ UN7.5.1/PG/2015, Indonesia.

\section{REFERENCES}

Ardyan, E. 2016. Market sensing capability and SMEs performance: The mediating role of product innovativeness success. Business \& Economics Review. 25 (2): 1-18.

Barney, J. B. 1991. Firm Resources and Sustained Competitive Advantage. Journal of Management, 17 (1): 99-120. doi: $10.1177 / 014920639101700108$

Buttle, F. 2004. Customer Relationship Management: Concept and Tool Elsevieer Worth Heineman.

Chien, S. Y \& Tsai, C. H. 2012. Dynamic capability, knowledge, learning, and firm performance. Journal of Oranizational Change Management. 25 (3): 434-444.

Cohen, D \& Prusak, L. 2001. In Good Company: 
Naili Farida, et al. / Model of Relationship Marketing and E-Commerce in...

How Social Capital Makes Organizations Work. Massachuset: Harvard Business School Press.

Coleman, J. S. 1988. Social capital in the creation of human capital. The American Journal of Sociology: 94. 95-120.

De Wulf, K \& Odekerken-Schroder, G. 2000. The Influence Seller Relationship Orientation and Buyer Relationship Process on Trust Commitment and Behavioral Loyalty in a Consumer Environment. Working Paper Series.

Farida, N. 2016. Determinants of marketing performance: innovation, market capabilities and marketing performance. Jurnal Dinamika Manajemen. 7 (1): 59-65.

Ferdinand, A. 2000. Manajemen Pemasaran: Sebuah pendekatan Strategik. Program Magister Manajemen. Semarang: Badan Penerbit Universitas Diponegoro.

Ferdinand, A. 2005. Modal Sosial dan Keunggulan Bersaing: Wajah Strategi Pemasaran. Semarang: Badan Penerbit Universitas Diponegoro.

Ghozali, I. 2008. Model Persamaan: Konsep dan Aplikasi dengan Program AMOS 16. Semarang: Badan Penerbit UNDIP.

Griffith, A., Noble, S. M \& Chen, Q. 2006. The performance implications of entrepreneurial proclivity: A dynamic capabilities approach. Journal of Retailing. 82 (1): 51-62.

Haroon, M \& Kocak, A. 2011. The Relationship Between Entrepreneurial Orientation Dynamic Capabilities and Firm Performance: An Exploratory Study of Small Turkish Firms. International Journal of Business and Globalization. 7 (3): 351-366.

Ismail, T. 2015. Social capital and organizational performance: Empirical study of Small to Medium Sized Enterprises (SME) in Indonesia. International Journal of Entrepreneurship. 19: 60-73.

Kohli, A. K \& Jaworski, B. J. 1990. Market Orientation: The Construct,Research Propositions, and Managerial Implications. Journal of Marketing. 54 (2): 1-18.

McDermott, C. M \& Prajogo, D. I. 2012. Service innovation and performance in SMEs. International Journal of Operations \& Production Management. 32 (2): 216-237.

Narver, J. C \& Slater, S. F. 1990. The effect of a market orientation on business profitability. Journal of Marketing. 54 (4): 20-35.
Nugroho, P. S \& Setyawan, A. A. 2015. Permoderasian Modal Sosial Pad Pengaruh Entrepreneur Terhadap Peningkatan Kinerja Organisasi (Studi Empiris pada UKM Di Surakarta. Benefit Jurnal Manajemen dan Bisnis. 19 (1): 80-94.

Otero-Neira, C., Lindman, M. T \& Fernandez, M. J. 2009. Innovation and Performance in SME Furniture Industries. Marketing Intelligence \& Planning. 27 (2): 216-232.

Pavlou, P. A \& El Sawy, O. A. 2011. Understanding the elusive Black Box of Dynamic Capabilities. Decision Sciences. 42 (1): 239-273.

Power, D. 2005. Determinats of business-to-business e-commerce implementation and performance a structural model. Supply Chain Management: An International Journal. 10 (2): 96-113.

Salwani, M. I., Marthandan, G., Norzaidi, M. D \& Chong, S. C. 2009. E-commerce usage and business performance in the Malaysian tourism sector: Empirical Research. Information \& Computer Security. 17 (2): 166-185.

Sok, P., O'cass, A \& Sok, M. K. 2013. Achieving superior SME performance: Overarching role of marketing, innovation, and learning capabilities. Australasian Marketing Journal. 21 (3): 161-167.

Syafruddin, C. 2003. Relationship Marketing: Inovasi Pemasaran Yang Membuat Pelanggan Bertekuk Lutut. Jakarta: PT. Gramedia Pustaka Utama.

Tjiptono, F \& Chandra, G. 2012. Pemasaran Strategik. Yogyakarta: ANDI.

Voss, G. B \& Voss, Z. G. 2000. Strategic Orientation and Firm Performance in an Artistic Environment. Journal of Marketing. 64 (1): 67-83.

Weerawardana, J. 2003. Exploring the role of market learning capability in competitive strategy. European Journal of Marketing. 37 (3/4): 407-409. doi: 10.1108/03090560310459023

Wiklund, J. 1999. Sustainable of entrepreneurial orientation performance relationship. Entrepreneurship Theory and Practice. 24 (1): 37-48.

Yang, Z., Shi, Y \& Yan, H. 2016. Analysis on pure ecommerce congestion effect, productivity effect and profitability in China. Socio-Economic Planning Science, in Press, Corrected Proof.

Zheng, C., O’Neill, G \& Maorrison, M. 2009. Enhancing Chinese SME performance through innovative HR practices. Personnel Review. 38 (2): 175-194. 